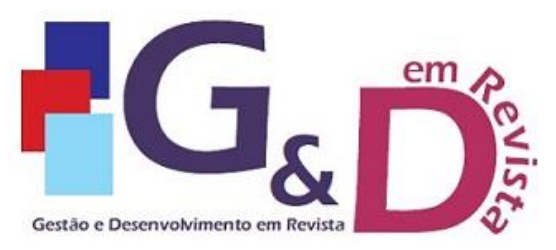

Gestão e Desenvolvimento em Revista V. 6, N. 1, jan-jun/2020, p. 77-93.

ISSN online: $2446-8738$

Artigo recebido em: 09/04/2020

Artigo aprovado em: 18/06/2020

\title{
ANALYSIS OF THE RELATIONSHIP BETWEEN COOPERATION INTENSITY AND EXPORT PERFORMANCE: A TAXONOMIC PROPOSAL
}

\author{
Adriana Gresielly Fabrini \\ Graduação em Administração com ênfase em Comércio Exterior. Mestrado em Enqenharia de \\ Produção. Doutorado em Administração. Atualmente é professora da Universidade Estadual de Ponta \\ Grossa. \\ E-mail: adrianafabrini@uepg.br
}

Cesar Eduardo Abud Limas

Graduação em Administracão. Mestrado em Engenharia de Produção. Doutorado em Administração. Atualmente é professora da Universidade Estadual de Ponta Grossa.

E-mail: cesar@cesarabud.com.br

\begin{abstract}
This study identifies three distinct levels of cooperation among Brazilian exporting companies and explores how cooperation intensity is related to export performance. Through a cluster analysis, a three-level taxonomy was proposed for inter-organizational cooperation, which are operational, tactical, and strategic cooperation. Although data were collected for 157 exporting companies located in the State of Paraná, Brazil, in January-February, 2018, the Qui-Square statistical test show the findings reached can be extended to the population. The results state that the more intense the asset sharing with other companies, the higher the export performance of the companies in the sample. It was found that there is an increase of approximately $13 \%$ in export performance when the number of assets shared increase from 2 to 8 .
\end{abstract}

Keywords: Multi-Party Cooperation. Business Performance. Cluster Analysis. Export Performance.

\section{Resumo}

Este estudo identifica três níveis distintos de cooperação entre empresas brasileiras exportadoras e explora como a intensidade de cooperação está relacionada ao desempenho exportador. Através de uma análise de cluster, uma taxonomia de três níveis foi proposta para a cooperação interorganizacional, que é cooperação operacional, tática e estratégica. Embora os dados tenham sido coletados para 157 empresas exportadoras localizadas no Estado do Paraná, no período de janeiro a fevereiro de 2018, o teste estatístico Qui-Quadrado mostra que os resultados alcançados podem ser generalizados à população. Os resultados afirmam que quanto mais intenso o compartilhamento de ativos com outras empresas, maior o desempenho exportador das empresas internacionalizadas. Verificou-se que há um aumento de aproximadamente $13 \%$ no desempenho das exportações quando o número de ativos compartilhados aumenta de 2 para 8.

Palavras-Chave: Cooperação. Desempenho Exportador. Análise de Cluster. Brasil. 


\section{INTRODUCTION}

In developing countries, micro and small companies tend to ignore the fact that the analysis, implementation, and maintenance of cooperative relationships increase competitiveness in internationalization (BLYLER e COFF, 2003; FABRINI, 2018; FERNHABER e LI, 2013; CIRAVEGNA, et al, 2014).

Vasilchenko and Morrish (2011) and Eberhard and Craig (2013) have shown that the entry, survival, growth, and international success of a firm requires the development of resources and capabilities that can be obtained through sharing assets-information, knowledge, resources, incentives, and others-between partner companies.

Two theoretical approaches advocate the development of specific resources and capabilities through cooperation strategies, which increase internationalization results - cooperation theory and internationalization theories (RINDOV e KOTHA, 2001; PROTOGEROU, et al., 2008; PAVLOU e SAWY, 2011; LIN e WU, 2014).

The first construct of this study is extracted from cooperation theory. This theory is based on two main pillars: evolution theory and game theory. One of the main aspects of cooperation theory is that cooperation between companies is effective when those seeking to achieve joint or individual goals, share resources, and/or capabilities in a reciprocal and long-term way (AXELROD, 1984).

The second construct-export performance-is drawn from internationalization theories. These theories contain two theoretical approacheseconomic and behavioral-to understand how and why companies internationalize, considering export performance is a metric of organizational involvement in foreign operations (WELCH e LUOSTARINEN, 1988).

This study aims to understand internationalized companies, most of which are micro and small companies, located outside the opportunities offered by the international market when answering the following research question - what is the relationship between cooperation intensity and export performance for internationalized companies?

The findings show in this work were obtained through a survey applied in a sample extracted of companies take placed in the State of Paraná, but a specific statistic test (Qui-Square) infer the behavior of the companies' sample is significant in relation all Brazilian exporting companies. So, the results can be generalized from the sample to the population. Another contribution of this paper is the identification of three company clusters, depending on cooperation intensity with third partiesoperational cooperation, tactical cooperation, and strategic cooperation-where the number of assets shared with the strongest partners is the main indicator for distinguishing them.

This typology, for future researches purposes, indicates that business managers in the strategic cooperation cluster, especially those who consider internationalization a strategic goal, are more aware of the role of cooperation.

\section{LITERATURE REVIEW}

\subsection{COOPERATION IN THE AXELROD PERSPECTIVE}

The discussions on cooperation between agents and the need for external controls and enforcement, for instance, are not recent. One of the earliest studies on 
the subject was proposed by Hobbes (1651/1962), where the author argues that before the existence of governments, agents driven by selfish interests, sought the domination of nature under cruel competition, and made life "lonely, poor, hard, brutal, and short" (HOBBES 1651/1962, p.100). Hence, there would have been no development of cooperation without the existence of a central authority.

Especially since the 20th century, authors such as Smith (1906), Schelling (1978), Hardin (1982), Taylor (1987), Margolis (1982), Axelrod (1984), among others, have shed light on cooperation promoted without the need for solution as proposed by Hobbes.

One of the more relevant features of the cooperation theory examines how agents, allegedly involved in self-interests, can freely adopt cooperative actions that have not been imposed by a central authority. Perhaps, the most outstanding work in this respect is that of Axelrod (1984), who analyzed the factors conducive to cooperation. Among other factors valuing cooperation rather than competition, the author emphasizes education, the long-term perspective, and appropriate definition of payoffs.

The cooperation theory, presented by Axelrod (1984), analyzes the motivations that lead rational agents who, in pursuit of their self-interests, cooperate in an environment free of central authority that imposes reciprocity. The hypotheses and conclusions presented by the author are derived from game theory, including Nash equilibrium.

Moreover, Axelrod (1984) pointed out five strategic changes internal to the companies capable of promoting cooperation: enlarge the shadow of the future, change the payoffs, teach people to care about each other, teach reciprocity, and improve recognition abilities.

One of the assumptions made in this study is that the strategic changes proposed in the cooperation theory, for promoting cooperation, will cause internationalized companies to migrate from one cluster to another, directly affecting their international performance. Therefore, these five changes are described below.

On the first strategy for promoting cooperation, Axelrod (1984, p.126) states:

Mutual cooperation can be stable if the future is sufficiently important relative to the present. This is because the players can each use an implicit threat of retaliation against the other's defection-if the interaction will last long enough to make the threat effective.

According to this theory, there are two ways to enlarge the shadow of the future: "by making the interactions more durable, and by making them more frequent" (AXELROD, 1984, p.129). The main example quoted by the author was the "live-andlet-live" system developed in the trenches of World War I, where the soldiers knew that interactions with enemy troops would be long-lasting and prolonged and motivated stable patterns of cooperation based on reciprocity.

To increase the frequency of interactions between two agents, Axelrod (1984, p.130) proposes to keep away from others "any form of specialization tending to restrict interactions to only few others would tend to make the interactions with those few more frequent. This is one reason why cooperation emerges more readily in small towns than in large cities".

Intensifying the interactions so that some agents interact more often helps stabilize and maintain cooperation, especially when agents use lenient strategies, such as "tit for tat". Since the players are aware of the inherent payback in mutual 


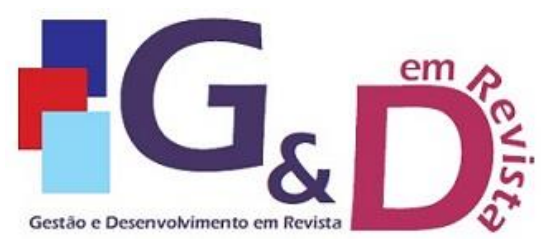

Gestão e Desenvolvimento em Revista V. 6, N. 1, jan-jun/2020, p. 77-93.

ISSN online: $2446-8738$

Artigo recebido em: 09/04/2020

Artigo aprovado em: 18/06/2020

cooperation, they are never the first to defect. Thus, gentle strategies can protect them in ways that cruel strategies cannot.

The second strategy to promote cooperation is to change the payoffs.

...to promote cooperation through modification of the payoffs, it is not necessary to go so far as to eliminate the tension between the sort-run incentive to defect and the longer-run incentive to achieve mutual cooperation, it is only necessary to make the long-term incentive for mutual cooperation greater than the short-term incentive for defection (AXELROD, 1984, p.134).

Considering North's (1990, p.3) assertion

Institutions are the rules of the game in a society or, more formally, are the humanly devised constraints that shape human interaction. In consequence they structure incentives in human exchange, whether political, social, or economic. Institutional change shapes the way societies evolve through time and hence, is the key to understanding historical change.

And comparing it with Axelrod's (1984, p.133) statement

What governments do is to change the effective pay offs. Is you avoid paying your taxes, you must face the possibility of being caught and sent to jail. This prospect makes the choice of defection less attractive. Even quasigovernments can enforce their laws by changing the payoffs faced by the players.

It is possible to affirm that institutions play the fundamental role of changing the payoffs through what North (1990, p.57) called "enforcement"

There are two parts to an institution's assuring cooperation. First, it is necessary to form a communications mechanism that provides the information necessary to know when punishment is required. By making available the relevant information, institutions make possible the policing of defections. Typically they economize on information, so, for example, players need no longer know the entire past history of any partner. Second, because punishment is often a public good in which the community benefits but the costs are borne by a small set of individuals, institutions must also provide incentives for those individuals to carry out punishment when called on to do so.

The third strategy quoted by Axelrod (1984, p.135) is to teach people to care about each other or attend to the welfare of others. "Without doubt, a society of such caring people will have an easier time attaining cooperation among its members, even when caught in an iterated Prisoner's Dilemma".

This strategy refers to a term widely studied by lawyers, psychologists, political and social scientists, economists, and game theorists: altruism.

Altruism among people can also be sustained through socialization. But here is a serious problem. A selfish individual can receive the benefits of another's altruism and not pay the welfare costs of being generous in return...Such people need to be treated differently than more considerate people, lest we be exploited by them. This suggest that the costs of altruism can be controlled by being altruistic to everyone at first, and thereafter only to those who show similar feelings. But this quickly takes one back to reciprocity as the basis for cooperation (AXELROD, 1984, p.135-136). 
The fourth cooperative strategy is based on reciprocity, since it "allows the other player to get the reward for mutual cooperation, which is the same payoff it gets for itself when both strategies are doing their best" (AXELROD, 1984, p.137).

Teaching reciprocity grants self-policing to the agent because, using the "tit for tat" strategy ensures punishment through fewer payoffs to the less cooperative agents. Building a rewarding relationship in the present minimizes the number of non-cooperative agents in the future (AXELROD, 1984).

The psychologist Calfee (1981) recommended that reciprocity be addressed in schools in his work "Cognitive Psychology and Educational Practice" on the strategic feature of "tit for tat".

To maintain and promote cooperation, it is important to recognize the past interactions with the present agents and remember the essential characteristics of these relations. "The expanded ability to recognize individuals with whom one has already interacted allows humans to develop a much richer set of cooperative relationship than birds can" (AXELROD, 1984, p.140).

\subsection{COOPERATION AND INTERNATIONALIZATION}

After analyzing some of the most recent papers published in international journals that combined cooperation and internationalization, it was verified that there still exist possibilities for further exploration on the subjects.

Most of the studies analyzed focus on the process of cooperation and internationalization in medium and small-sized companies (CIRAVEGNA, et al., 2014, FRANCIONI, et al., 2017; PINHO e PRANGE, 2016; ZHANG, et al., 2016).

Among the main conclusions presented by these papers, it was identified that: clients help in international expansion through indications (FRANCIONI, et. al., 2017), there is a positive effect between international entrepreneurship and the degree of internationalization (ZHANG, et al. , 2016), disruption and consolidation capabilities positively affect international performance (PINHO e PRANGE, 2016), companies use cooperation as a support to access international markets (CIRAVEGNA, et al., 2014), and formal and informal cooperation positively induce internationalization process of new ventures (FERNHABER e LI, 2013).

These studies also presented suggestions for futures studies to fill the theoretical and empirical gaps. Additionally, it was found that there are three elements underexplored with respect to cooperation and internationalization: to analyze the impacts of cooperation on internationalization in different industries, to understand the impact of different types of cooperation on the degree of internationalization, and to measure the data using longitudinal data (FERNHABER e LI, 2013; CIRAVEGNA, et al., 2014; PINHO e PRANGE, 2016; ZHANG et al., 2016; FRANCIONI, et al., 2017).

This survey was useful to understand how academics analyze this relationship and to verify if there is still a large unexplored area for those who intend to investigate this phenomenon in depth or through other perspectives.

All these processes have culminated in the elaboration of the general objective of this paper: Analysis of the relationship between cooperation intensity and export performance of internationalized companies.

The general objective narrows down some of the theoretical gaps highlighted by several authors, especially by Francioni, et al. (2017) on how cooperation 
influences the internationalization of companies that operate in distinct sectors of economic activity and times of operation. Moreover, the study by Zhang et al. (2016) on the impact of cooperation by moderating the relationship between international entrepreneur features and international performance, the authors suggested that different types of cooperation agreements should be included in the analyses.

\section{METHODOLOGY}

\subsection{POPULATION AND SAMPLE}

The data from the Brazil (2017) shows that, in 2016, a total of 25,037 Brazilian companies exported goods or services. This population is composed of companies of different industries, with a diverse range of activities, and classified into six categories based on export value-over US\$ 100 million, between US\$50 and 100 million, between US\$10 and 50 million, between US $\$ 5$ and 10 million, between US\$ 1 and 5 million, and less than US\$ 1 million.

The population selected for this work comprises 2,312 companies located in the State of Paraná, Brazil that account for $9.2 \%$ of Brazilian exporting companies.

The quantitative data were collected through a self-administered survey conducted between January-February 2018.

The self-administered survey was chosen keeping in mind the following: considering that approximately $20 \%$ of the respondents would properly answer the survey, there was a need to contact 750 companies. From the list of companies sourced from MDIC, every third company was selected for the sample.

Thus, the sample is characterized as systematic, which for Babie (2001, p.136) "in practice, the systematic sample is virtually identical to simple random sampling." That is, each element of the population has an equal probability of being included in the sample (BRYMAN, 2005).

The questionnaire was sent to the electronic mail addresses of the managers in charge of export processes. After the data was tabulated, 20 were excluded because they had some problems in the filling, such as partially-filled questionnaire, key information declared as confidential, or only one option filled. The final sample for the quantitative analysis consisted of 157 companies, that is, $24 \%$ of the companies approached.

The sample had companies of different sizes, operating times, industry, and export value, in other words, a mirror image of the Brazilian exporting companies.

\subsection{MEASUREMENT}

Keeping the conceptual evolution of authors like Kropotkin (1842, 2009), Axelrod (1984), O'Brien (1968), Wahba (1971), Hafezalkotob (2017), and others in mind, it was decided that the definition of cooperation given by Anderson and Narus (1990: 45) should be used - "similar or complementary coordinated actions taken by firms in independent relationship to achieve mutual outcomes or singular outcomes with expected reciprocation over time."

Secondly, based on Cao and Zhang's (2011) study, cooperation intensity is measured using the following variables: sharing information, collaborative communication, goal congruence, decision synchronization, incentive alignment, resource sharing, joint knowledge creation, and risk sharing. 
Finally, export performance is analyzed according to Welch and Luostarinen's (1988, p.36) concept of "the process of increasing involvement in international operations." Operationally, this concept was measured with four variables extracted from the work of de Hitt, et al. (2011), and three others extracted from Sullivan's (1994): performance attribute, structural attribute, and attitudinal attribute.

\subsection{DATA ANALYSIS}

Considering the complexity of characterizing cooperation intensity among internationalized companies in export performance, a multivariate analysis of data, specifically cluster analysis, was used to better understand the phenomenon.

Cluster analysis is a multivariate technique that aggregates objects based on their features. This technically sorts the objects such that each one is similar to the others in the cluster. Hence, the cluster has high internal homogeneity (within the cluster) and high external heterogeneity (between clusters) (HAIR JR, et al., 2009).

Hierarchical method was selected for the partition procedure because there are no predefined number of clusters. The distance calculation method and clustering algorithm used were square Euclidian distance and Ward's method, respectively. The construct "cooperation" was selected as the grouping variable.

\section{RESULTS}

The application of cluster analysis was based on the analysis of the sample size. As stated by Hair Jr et. al. (2009, p.439):

If the objectives of the analysis require the identification of small groups within the population, the researcher should look for large samples. If the researcher, however, is interested in large groups...then the distinction between an atypical observation and a representative of a small group is less important and both can be treated of a similar way.

Since the objective of this work is to represent the inherent structure in large groups with proportionally similar features, there was no concern with sample size or with atypical observations. It is understood that, on average, these observations will be similar to those of most of the other companies in the cluster.

Conversely, it was relevant to test the representativeness of the sample. Hence, the export values of sample companies were analyzed against the data from Brazilian exporting companies.

For this, chi-square statistical test was performed. Chi-square is a standardized measure of comparison of observed frequencies of cells in a contingency table with expected frequencies, under the validity of a null hypothesis (Hair Jr et al., 2009).

Data from MDIC (2017) indicate that, in 2016, 93.7\% of Brazilian companies exported less than US\$10 million, 5.1\% exported between US\$10 million and 50 million, and $1.3 \%$ exported over US\$ 100 million. The distribution of sample companies by export value is shown in Table 1. 
Table 1 Export Value

\begin{tabular}{lcc}
\hline \multicolumn{1}{c}{ Export Value } & Frequency & Percentage \\
\hline Over US\$ 100 million & 2 & $1.2 \%$ \\
Between US\$ 10 and 50 million & 11 & $6.9 \%$ \\
Between US\$ 5 and 10 million & 4 & $2.4 \%$ \\
Between US\$ 1 and 5 million & 37 & $23.4 \%$ \\
Less than US\$ 1 million & 103 & $65.8 \%$
\end{tabular}

Source: the authors

The export value range of between US $\$ 50$ and 100 million is absent from the table because the sample companies do not operate in this range. Table 2 presents the results of the chi-square test.

Table 2 Chi-square test: export value

\begin{tabular}{llll}
\hline & Observed value & Expected value & Residual \\
\hline Less than US\$ 10 million & 144 & 147 & -4 \\
Between US\$ 10 and million & 11 & 8 & 3 \\
Over US\$ 100 million & 2 & 2 & 0 \\
Chi-Square & 1.186 & & \\
Sd & 2 & & \\
Significance & 0.553 & & \\
Source: the authors & &
\end{tabular}

It can be inferred that the export values of the sample companies is statistically significant in relation to all Brazilian exporting companies. The rejection of null hypothesis suggests that the sample is significant in relation to the population, therefore, the results can be generalized for all Brazilian exporting companies.

It is also important to point out that the variables of the cooperation construct were not standardized since all its variables are measured on the same scale of response, that is, a 5-point Likert scale.

Next, to enhance the results quality, multicollinearity test was conducted. According to Hair Jr et al. (2009), multicollinearity measures the extent to which a variable can be explained by other variables of the analysis. That is, the variables of the model have an interrelationship between them. So, "the researcher is encouraged to examine the variables used in cluster analyses" (p.447).

Table 3 presents the results of multicollinearity test of the variables of the construct cooperation. 
Table 3 Multicollinearity test

\begin{tabular}{lll}
\hline Model & \multicolumn{2}{l}{ Multicollinearity test } \\
\hline & Tolerance & VIF \\
\hline Information sharing & 0.387 & 2.581 \\
\hline Collaborative communication & 0.441 & 2.267 \\
\hline Goal congruence & 0.510 & 1.961 \\
\hline Decision synchronized & 0.457 & 2.187 \\
\hline Incentive alignment & 0.393 & 2.543 \\
\hline Resource sharing & 0.521 & 1.918 \\
\hline Joint knowledge creation & 0.543 & 1.842 \\
\hline Risk sharing & 0.551 & 1.816 \\
\hline Source: the authors & &
\end{tabular}

Hair Jr et al. (2009, p.125) stated "a tolerance value equal or less than 0.20 and a VIF value equal or greater than 5 indicates a potential multicollinearity problem." We find there is no multicollinearity between the variables that measure the construct.

Following this, using hierarchical cluster analysis three distinct groups were identified. These groups were tested using ANOVA, whose results are shown in Table 4.

Table 4 Variance Analysis: ANOVA

\begin{tabular}{lllll}
\hline Clusters & Observations & Average & Standard Deviation & Error \\
\hline 1 & 59 & 2.9 & 0.65 & 0.08 \\
\hline 2 & 45 & 4.2 & 0.58 & 0.08 \\
\hline 3 & 53 & 4.9 & 0.6 & 0.08 \\
\hline Total & 157 & 4.0 & 1.08 & 0.08 \\
\hline
\end{tabular}

Homogeneity's variance test - Levene $=0.576$ Sig. 0.563

ANOVA = Sig. 0.000

Source: the authors

Using Levene test $($ Sig. $=0.576)$ and ANOVA (Sig. 0.000), we reject the null hypothesis of equality of variance between the three groups formed through cluster analysis.

The post-hoc tests of Tukey and Bonferroni were then carried out, which confirmed that the three clusters are statistically different from each other. 
Table 5 Post-hoc tests

\begin{tabular}{|c|c|c|c|c|c|}
\hline \multicolumn{6}{|l|}{ Tukey HSD } \\
\hline Wart's Method (I) & Wart $(\mathrm{J})$ & Difference betu & ween the means $(\mathrm{I}-\mathrm{J})$ & Error & Sig. \\
\hline \multirow[t]{2}{*}{1} & 2 & & $-1.35^{\star}$ & 0.12 & 0.000 \\
\hline & 3 & & $-2.06^{*}$ & 0.11 & 0.000 \\
\hline \multirow[t]{2}{*}{2} & 1 & & $1.35^{*}$ & 0.12 & 0.000 \\
\hline & 3 & & $-0.71^{*}$ & 0.12 & 0.000 \\
\hline \multirow[t]{2}{*}{3} & 1 & & $2.06^{*}$ & 0.11 & 0.000 \\
\hline & 2 & & $0.71^{*}$ & 0.12 & 0.000 \\
\hline \multicolumn{6}{|l|}{ Bonferroni } \\
\hline Wart's Method (I) & Wart $(\mathrm{J})$ & Difference betv & ween the means $(\mathrm{I}-\mathrm{J})$ & Error & Sig. \\
\hline \multirow[t]{2}{*}{1} & 2 & & $-1.35^{\star}$ & 0.12 & 0.000 \\
\hline & 3 & & $-2.06^{*}$ & 0.11 & 0.000 \\
\hline \multirow[t]{2}{*}{2} & 1 & & $1.35^{\star}$ & 0.12 & 0.000 \\
\hline & 3 & & $-0.71^{*}$ & 0.12 & 0.000 \\
\hline \multirow[t]{2}{*}{3} & 1 & & $2.06^{*}$ & 0.11 & 0.000 \\
\hline & 2 & & $0.71^{*}$ & 0.12 & 0.000 \\
\hline \multicolumn{6}{|c|}{ Alpha homogenic subsets $=0.05$} \\
\hline Ward's Method & $\mathrm{N}$ & 1 & 2 & & 3 \\
\hline 2 & 59 & 2.92 & & & \\
\hline 1 & 45 & & 4.27 & & \\
\hline 3 & 53 & & & & 4.98 \\
\hline Sig. & & 1.00 & 1.00 & & 1.00 \\
\hline
\end{tabular}

It was verified that the groups generated from the cluster analysis were statistically different from each other in relation to cooperation of companies in the sample. The identification of differences and similarities within and between groups was then started.

\subsection{COMPARISON BETWEEN GROUPS}

The clusters were segmented into three groups composed of 59,45 , and 53 companies. Figure 1 shows the behavior of each of the variables in the cooperation construct in the three generated clusters. 


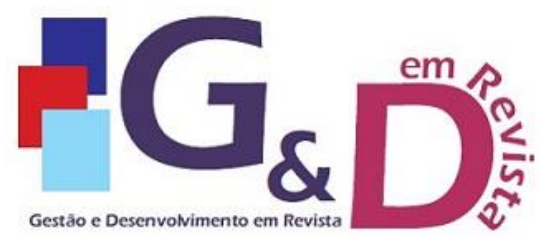

Gestão e Desenvolvimento em Revista V. 6, N. 1, jan-jun/2020, p. 77-93.

ISSN online: $2446-8738$

Artigo recebido em: 09/04/2020

Artigo aprovado em: 18/06/2020

Figure 1 - Comparison of the construct variables cooperation in the three clusters

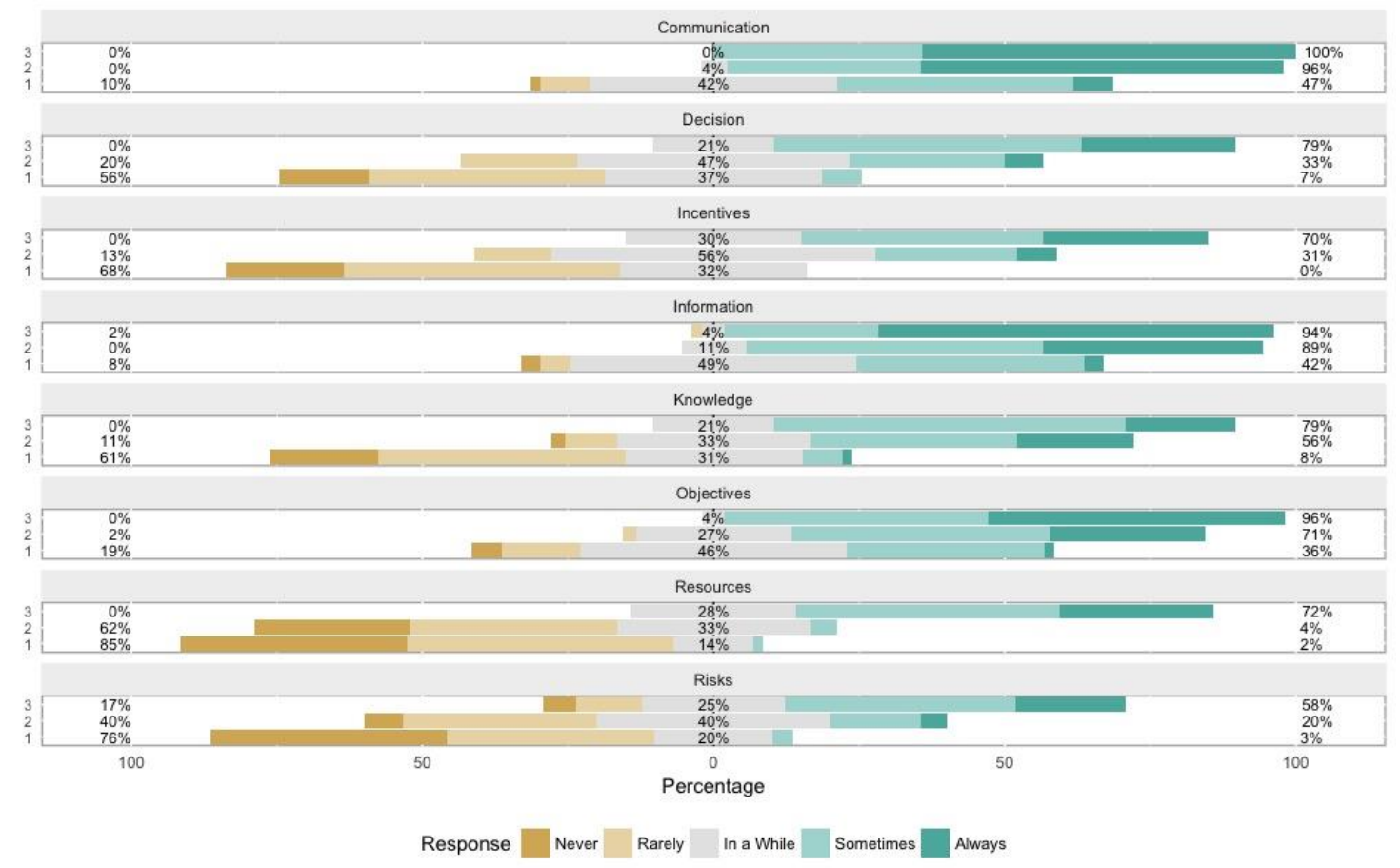

Source: the authors

To analyze Figure 1, we set $40 \%$ as the reference percentage for responses higher than the neutral range (the option "sometimes") on the 5-point Likert scale. Thus, it can be seen that the most intensively and frequently shared assets among the companies in cluster 1 are communication and information, with $47 \%$ and $42 \%$ respectively.

In the second cluster, composed of 45 companies, communication, information, objectives, and knowledge are the most frequently shared assets between the sample companies and their strongest partners.

Finally, the third cluster consists of companies that intensively and frequently share all the assets. This result is obtained when it is verified that the 8 assets are always or almost always shared with more than $40 \%$ of the sample companies.

Considering the intensity scale and type of asset shared in each of the three clusters, the first cluster is called operational cooperation, the second tactical cooperation, and the third strategic cooperation.

After the segmentation of the companies into the three clusters, export performance construct in each of them was verified and showed by Table 6 .

Table 6 International performance of the companies in the clusters

\begin{tabular}{lccc}
\hline Question & $\begin{array}{c}\text { Operational } \\
\text { Cooperation }\end{array}$ & $\begin{array}{c}\text { Tactical } \\
\text { Cooperation }\end{array}$ & $\begin{array}{c}\text { Strategic } \\
\text { Cooperation }\end{array}$ \\
\hline$\%$ of sales from exports & $23.2 \%$ & $24.7 \%$ & $26.2 \%$ \\
$\%$ of profit from exports & $22.5 \%$ & $20.0 \%$ & $25.5 \%$ \\
$\%$ average & $22.8 \%$ & $22.5 \%$ & $25.8 \%$
\end{tabular}

Source: the authors 
Of the five variables used to measure the export performance construct, the percentage of sales and profit from exports correspond to export performance. Hence, they were used for comparison.

On average, for the sample companies, the higher the cooperation, the higher is the export performance. Further, the percentage change in export performance between the three clusters was calculated (Table 7).

Table 7 Percentage change in export performance due to cooperation

\begin{tabular}{|c|c|c|c|}
\hline & $\begin{array}{l}2 \text { to } 4 \text { sharing } \\
\text { assets }\end{array}$ & $\begin{array}{l}4 \text { to } 8 \text { sharing } \\
\text { assets }\end{array}$ & $\begin{array}{l}2 \text { to } 8 \text { sharing } \\
\text { assets }\end{array}$ \\
\hline Export Performance & $\Delta \%$ & $\Delta \%$ & $\Delta \%$ \\
\hline$\%$ of sales from exports & $6.4 \%$ & $6 \%$ & $12.9 \%$ \\
\hline$\%$ of profit from exports & $-11.1 \%$ & $27.5 \%$ & $13.3 \%$ \\
\hline $\begin{array}{l}\text { Average } \% \text { change in export } \\
\text { performance }\end{array}$ & $-1.3 \%$ & $14.6 \%$ & $13.1 \%$ \\
\hline
\end{tabular}

Source: the authors

This comparison should be used strategically by companies wishing to increase export performance through cooperation. Companies with international operation can, through exports, determine the intensity with which the assets will be shared and the percentage impact this change will have on export performance.

The cluster analysis made it possible to draw a general profile of the companies in the segmented sample into three distinct groups. This technique is useful for the identification of patterns and distinctions between groups.

\section{DISCUSSION}

The relationship between cooperation intensity and export performance of companies in the State of Paraná was demonstrated through cluster analysis.

Of the 2,312 internationalized companies in the State of Paraná, sourced from the MDIC database, a questionnaire was administered to 635 companies and, through telephone and electronic mail, 157 respondents were obtained.

Using the profile of the respondent companies, the results obtained can be generalized to all Brazilian exporting companies. In other words, it is relevant for all Brazilian exporting companies to analyze their cooperation with third parties as a learning and strategy alternative that will lead to higher levels of exports and direct investment abroad.

It was verified that all the companies surveyed interact with third parties, to a greater or lesser extent. However, considering the essential elements of the theory of cooperation, whose most relevant works were published by Kropotkin $(1902,2009)$, Axelrod (1984), among others, we intend, initially to analyze the level of cooperation of internationalized companies based in the State of Paraná, Brazil.

The use of cluster analysis made it possible to segment the 157 companies into three groups: operational cooperation, tactical cooperation, and strategic cooperation.

The 59 companies classified as operational cooperation are those that care about maintaining active and frequent communication with their strongest partners. 
The other assets are rarely shared. They are young companies with a low level of internationalization.

The second cluster, called tactical cooperation, is composed of 45 companies whose most shared assets are communication, information, decision, knowledge, and objectives. The other assets are rarely shared. This cluster is made up of mature companies, which export up to US\$ 5 million per year.

Finally, the third cluster, made up of 53 companies, was named strategic cooperation. In this group are the companies that frequently share all eight assets surveyed. These are mature companies, which on average export up to US\$ 5 million per year. This group brings together the largest number of companies that carry out foreign direct investment. That is, they are organizations with intense international activity and with deep commitment in foreign markets.

Finally, it was verified that in relation to the cooperation construct, what differentiates the three groups is the intensity and frequency of sharing assets with their strongest partners and this distinction is directly related to the international performance of the companies.

That is, cooperation is shown to be a behavioral variable, which depends more on people's awareness and willingness to trust each other and get involved in reciprocal sharing of assets than on the structure of relationships they maintain.

Cluster analysis also made it possible to evaluate the impact of cooperation on international performance. Considering each of the three clusters, it was verified that the higher the cooperation, the greater is the international involvement, especially for companies that carry out direct investment abroad.

This conclusion complements the findings of Gaur et al. (2014), who had evaluated the process of internationalization in an emerging economy and how the relationship between companies enables growing involvement in international operations.

In this sense, when there is an increase in the number of assets being shared, from 2 to 4 , the performance in exports remains practically stagnant. If the number of assets being shared increases from 4 to 8 , the positive impact on sales and profit from exports will be $13.1 \%$.

Finally, we conclude that the general research objective was achieved through this study. We found that the more intense the cooperation, the greater is the export performance of internationalized companies.

\subsection{EMPIRICAL IMPLICATIONS}

After proving that greater intensity of cooperation leads to greater export performance of internationalized companies, it is important to analyze the concrete and routine actions that can lead companies to higher levels of cooperation and sharing of assets. One way to achieve this goal is to increase cooperation as described by Axelrod (1984).

First, Axelrod (1984) proposes to increase the importance of the future in two ways: to make interactions continuous and frequent. For this, he suggests that the relationship between agents should be encouraged and widely exposed to stakeholders, minimizing the rapprochement of other opportunistic agents. Consequently, this "withdrawal" from other companies will lead to a strengthening of existing links. 
Operationally, companies can increase the importance of the future through more shopping, issuing more orders, acquiring new inputs, sharing new projects, making more visits, promoting joint training, organizing more frequent meetings, sponsoring joint events, sharing people, machines and physical space, develop local partners, favor reduced hierarchical structures, plan the layout to promote interaction, discuss problems and possible shared solutions, among others.

According to Axelrod (1984), a society constituted by caring people will find it easier to maintain cooperation between its members. Thus, teaching people to care for each other is an important way to promote cooperation.

Within companies, this can be done by encouraging information sharing, reducing distances, punishing selfish behaviors, promoting training, encouraging volunteer action, and so on.

Between two agents, to assure both that the other is doing the best possible and there are fair rewards, communication, and transparency between the parties. Further, it is important to develop capabilities that allow companies to recognize a partner from past interactions and remember relevant characteristics of those interactions.

Organizations can maintain an updated database of suppliers, customers, competitors, and outsourcers that it may have already negotiated with in the past. It is important to record quantitative data (price, payment, and delivery periods, the frequency of remittances, percentages of increases, discounts) and qualitative data (obstacles in negotiation, atypical situations, turbulence, joint solutions, shared goals, situations involving partners, and other companies/entities) that can be continuously accessed.

\section{LIMITATION AND SUGGESTIONS FOR FUTURE RESEARCH}

The following are the limitations of this study. We ignored the industrial sector that the sample companies belong to. A larger sample of firms, allowing segmentation or sample stratification by industry could yield different profiles of international performance based on specific capacities or different levels of cooperation.

A metric for the international performance of companies in emerging countries was not identified. For this reason, it is suggested that future research should focus on understanding the Brazilian business scenario and develop an instrument for measuring international performance consistent with national reality.

Conversely, there are many studies that used indicators of international performance different from those used in this study. Hence, a replication of this study using other performance indicators is encouraged.

This research adopted a cross-sectional design. Thus, the impact of cooperation on international performance over time has not been captured. Using long-term data will allow evaluation of not only the impact but also the evolution of the three constructs in different periods.

Despite these limitations, this study improves the theoretical and empirical understanding of the two constructs of cooperation and export performance, in isolation and in conjunction.

We also believe that the results of this study will encourage companies to internationalize in a more strategic way and enable organizations, governmental or 
non-governmental, to promote actions that encourage cooperation between agents, as it will directly reflect in the international performance of companies.

\section{REREFENCES}

ANDERSON, J. C; NARUS, J. A. A Model of Distributor Firm and Manufacturer Firm Working Partnerships. Journal of Marketing, v. 54, n. 1, p. 42, 1990.

AXELROD, R. The evolution of cooperation. New York Basic Books, Inc., 1984.

BABIE, E. Métodos de pesquisas de survey. Belo Horizonte: Editora UFMG, 2001.

BLYLER, M; COFF, R. W. Dynamic capabilities, social capital, and rent appropriation: Ties that split pies. Strategic Management Journal, v. 24, n. 7, p. 677686, 2003.

BRAZIL. Ministério da Economia. Empresas brasileiras importadoras e exportadoras. http://www.mdic.gov.br/index.php/comercio-exterior/estatisticas-de-comercio-

exterior/empresas-brasileiras-exportadoras-e-importadoras. Access: Dez 12, 2017.

BRYMAN, A. Research Methods and Organization Studies. Londres: Taylor \& Francis e-Library, 2005.

CALFEE, R. Cognitive psychology and educational practice. Washington: Amercian Educational Research Association, 1981.

CAO, M; ZHANG, Q. Supply chain collaboration: Impact on collaborative advantage and firm performance. Journal of Operations Management, v. 29, n. 3, p. 163-180, 2011.

CIRAVEGNA, L; LOPEZ, L; KUNDU, S. Country of origin and network effects on internationalization: A comparative study of SMEs from an emerging and developed economy. Journal of Business Research, v. 67, n. 5, p. 916-923, 2014.

EBERHARD, M; CRAIG, J. The evolving role of organisational and personal networks in international market venturing. Journal of World Business, v. 48, n. 3, p. 385-397, 2013.

FABRINI, A. G. Análise da relação entre a cooperação e o desempenho internacional mediada pelas capacidades dinâmicas de internacionalização. Tese. Universidade Positivo, 2018.

FERNHABER, S. A; LI, D. International exposure through network relationships: Implications for new venture internationalization. Journal of Business Venturing, $v$. 28, n. 2, p. 316-334, 2013.

FRANCIONI, B; VISSAK, T; MUSSO, F. Small Italian wine producers' internationalization: The role of network relationships in the emergence of late starters. International Business Review, v. 26, n. 1, p. 12-22, 2017. 
GAUR, A. S; KUMAR, V; SINGH, D. Institutions, resources, and internationalization of emerging economy firms. Journal of World Business, v. 49, n. 1, p. 12-20, 2014.

HAFEZALKOTOB, A. Competition, cooperation, and coopetition green supply chains under regulations on energy saving levels. Transportation Research Part E, v. 97, p. 228-250, 2017.

HAIR JR, J. F; BLACK, W. C; BABIN, B. J; ANDERSON, R. E; TATHAM, R. L. Análise multivariada de dados. 6. ed. ed. Porto Alegre: Bookman, 2009.

HARDIN, R. Collective actions. Baltimore: Johns Hopkins University Press, 1982.

HITT, M. A; IRELAND, R. D; HOSKISSON, R. E. Estratégia internacional. In: Administração estratégica: competitividade e globalização. 2. ed. ed. São Paulo: Cengage Learning, 2011.

HOBBES, T. Leviatan. New York: Collier Book, 1962.

KROPOTKIN, P. (1902, 1921). Ajuda mútua: um fator de evolução. São Sebastião: A Senhora Editora, 2009.

LIN, Y; WU, L. Y. Exploring the role of dynamic capabilities in firm performance under the resource-based view framework. Journal of Business Research, v. 67, n. 3, p. 407-413, 2014.

MARGOLIS, H. Selfish, altruism and rationality. Cambridge: Cambridge University Press, 1982.

NORTH, D. C. Institutions, institutional change and economic performance. Cambridge University Press, 1990.

O'BRIEN, G. The measurement of cooperation. Organizational Behavior and Human Performance, n. 3, p. 427-439, 1968.

PAVLOU. P. A; SAWY, O. A. E. Understanding the 'Black Box' of Dynamic Capabilities. Management Science, v. 92521, n. 1, p. 239-273, 2011.

PINHO, J. C; PRANGE, C. The effect of social networks and dynamic internationalization capabilities on international performance. Journal of World Business, v. 51, n. 3, p. 391-403, abr. 2016.

PROTOGEROU, A; CALOGHIROU, Y.; LIOUKAS, S. Dynamic capabilities and their indirect impact on firm performance. Entrepreneurship and innovation - Organization, Instituitions System and Region, p. 1-48, 2008.

RINDOVA, V. P; KOTHA, S. Continuous "morphing": competing through dynamic capabilities, form, and function. The Academy of Management Journal, v. 44, n. 6, p. 1263-1280, 2001. 
SCHELLING, T. C. Micromotives and macrobehavior. In: Schelling, T. (Ed.). Micromotives and macrobehavior. New York: Norton, p. 9-43, 1978.

SMITH, M. B. The first forty years of Washington society. New York: Scribner's, 1906.

SULLIVAN, D. Measuring the degree of internationalization of a firm. Journal of International Business Studies, n. October, p. 325-342, 1994.

TAYLOR, M. Anarchy and Cooperation. New York: Wiley, 1987.

VASILCHENKO, E; MORRISH, S. The Role of Entrepreneurial Networks in the Exploration and Exploitation of Internationalization Opportunities by Information and Communication Technology Firms. Journal of International Marketing, v. 19, n. 4, p. 88-105, 2011.

WAHBA, M. A. The effect of some dimensions of social power on cooperation in mixed-motive games. Organizational Behavior and Human Performance, n. 6, p. 235-247, 1971.

WELCH, L. S; LUOSTARINEN, R. Internationalization: Evolution of a Concept. Journal of General Management, v. 54, n. September, p. 34-55, 1988.

ZHANG, X; MA, X; WANG, Y; LI, X; HOU, D. What drives the internationalization of Chinese SMEs? The joint effects of international entrepreneurship characteristics, network ties, and firm ownership. International Business Review, v. 25, n. 2, p. 522-534, 2016. 